\title{
Role of CD4 Molecule in the Induction of Interleukin 2 and Interleukin 2 Receptor in Class II Major Histocompatibility Complex-restricted Antigen-specific T helper Clones T Cell Receptor/CD3 Complex Transmits CD4-dependent and CD4-independent Signals
}

\author{
Naoki Oyaizu, Narendra Chirmule, and Savita Pahwa \\ Department of Pediatrics, North Shore University Hospital-Cornell University Medical College, Manhasset, New York 11030
}

\begin{abstract}
The CD4 molecule plays an essential role in antigen-induced activation of $\mathbf{T}$ helper (Th) cells, but its contribution to signal transduction events resulting in physiologic $T$ cell function is ill defined. By utilizing anti-CD4 monoclonal antibodies (MAbs) that recognize distinct epitopes of $\mathrm{CD4}$, we have investigated the role of CD4 molecule in antigen-induced interleukin 2 (IL2) and IL-2 receptor (IL-2R) $\alpha$ chain expression in class II major histocompatibility complex-restricted antigen-specific human Th clones. Pretreatment of the Th clones with Leu3a resulted in a dose-dependent suppression of antigen-induced proliferative responses, inositol phosphate accumulation, increase in free cytoplasmic calcium ions $\left(\left[\mathrm{Ca}^{2+}\right]_{i}\right)$, IL-2 mRNA accumulation, IL-2 secretion, and membrane IL-2R expression. IL-2R mRNA accumulation, however, was unaffected even at highest Leu3a concentrations. Leu3a treatment did not affect bypass activation of $T$ cells with PMA plus ionomycin or activation via CD2 molecule. The MAb OKT4, which binds another domain of CD4, was not inhibitory. These results suggest that after $T$ cell antigen receptor-CD3 activation, IL-2 gene induction, IL-2 secretion, and membrane IL-2R expression are absolutely dependent upon participation of CD4 molecules, phosphatidylinositol (PI) hydrolysis, and increase in $\left[\mathrm{Ca}^{2+}\right]_{i}$. The requirement for $I L-2 R$ gene induction, however, occurs independently of CD4 molecule participation and PI hydrolysis. (J. Clin. Invest. 1992. 89:1807-1816.) Key words: cytokine receptor regulation - human immunodeficiency virus glycoprotein 120 receptor $\cdot$ lymphoproliferation $•$ Signal transduction $\cdot T$ cell activation
\end{abstract}

\section{Introduction}

The $\mathrm{T}$ cell antigen receptor ( $\left.\mathrm{TCR}^{1}\right)-\mathrm{CD}^{3}$ (TCR/CD3) complex recognizes foreign antigen in the context of the proper histo-

Address reprint requests to Dr. Pahwa, Room 303, Bio-Medical Research Building, North Shore University Hospital, 350 Community Drive, Manhasset, NY 11030.

Received for publication 28 June 1991 and in revised form $12 \mathrm{No}$ vember 1991 .

1. Abbreviations used in this paper: APC, antigen-presenting cell; CHX, cycloheximide; IL-2R, IL-2 receptor; IP, inositol phosphate; PFA, paraformaldehyde; PI, phosphatidylinositol; PKC, protein kinase C; PLC, phospholipase C; PPD, purified protein derivative; PTK, protein tyrosine kinase; sCD4, soluble CD4; TCR, T cell antigen receptor; TdR, thymidine; Th cell, $\mathrm{T}$ helper cell; $\mathrm{Tt}$, tetanus toxoid.

J. Clin. Invest.

(C) The American Society for Clinical Investigation, Inc. $0021-9738 / 92 / 06 / 1807 / 10 \$ 2.00$

Volume 89, June 1992, 1807-1816 compatibility molecule and transduces intracellular biochemical signals that eventually lead to distal biologic responses such as expression of lymphokine genes. The TCR/CD3 complex mediates antigen-specific activation, at least in part, through the production of inositol phospholipid-derived second messengers $(1,2)$. Triggering of the TCR/CD3 stimulates phospholipase C (PLC)-mediated hydrolysis of inositol phospholipids, resulting in the production of inositol phosphates (IPs) and diacylglycerol, the second messengers responsible for mobilization of cytoplasmic free calcium and activation of protein kinase $C$ (PKC) (3). Effective binding of the antigen and major histocompatibility complex (MHC) molecule on the antigenpresenting cell (APC) by a TCR constitutes the minimal requirement for an antigen-specific immune response. In the $\mathrm{CD}^{+} \mathrm{T}$ lymphocytes, specific antigen recognition and activation of $\mathrm{CD}^{+} \mathrm{T}$ cells also requires the engagement of the CD4 molecule. CD4, which is also the receptor for the human immunodeficiency (HIV) envelope glycoprotein, gp120, is known to bind a monomorphic region on the class II MHC molecule, thereby facilitating antigen recognition and inducing optimal $\mathrm{T}$ cell activation by increasing adhesion and signal transduction (4-7). Evidence is accumulating that CD4 and the TCR coordinately engage class II molecules to mediate an efficient cellular immune response (8-11), and that engaged CD4 may transmit a signal with an associated cytoplasmic tyrosine kinase, $\mathrm{p} 56^{\text {lck }}$ (12-14).

The regulatory role of CD4 was initially indicated by studies in which TCR/CD3-triggered activation was blocked by the addition of anti-CD4 mononclonal antibodies (MAbs), but the mechanism for this inhibition has not been clarified. Two different possibilities have been postulated: $(a)$ the effects could occur by generation of a negative signal (15-18), or $(b)$ by blocking of class II molecule interaction with $\mathrm{CD} 4$, hence preventing the formation of a required TCR/CD3/CD4 complex $(9,19)$. The current study is an effort to elucidate the physiologic role of CD4 in class II-restricted antigen-initiated T cell activation by utilizing two anti-CD4 MAbs (Leu3a and OKT4) that recognize distinct epitopes of CD4. Leu3a, but not OKT4, was found to inhibit antigen-driven phosphatidylinositol (PI) hydrolysis, increase in $\left[\mathrm{Ca}^{2+}\right]_{i}$, interleukin 2 (IL-2) mRNA induction, IL-2 secretion, and surface IL-2 receptor (IL-2R) expression. The effect of Leu3a was selective for the TCR/CD3 complex because neither bypass activation of the $T$ cells with phorbol 12-myristate 13-acetate (PMA) plus ionomycin nor activation elicited through the $\mathrm{CD} 2$ molecule was affected by such treatment. In contrast, Leu3a did not affect IL-2R mRNA induction even when used at concentrations that completely inhibited initial accumulation of inositol phosphates and increase in $\left[\mathrm{Ca}^{2+}\right]_{i}$. These results strongly suggest that CD4 molecules play a critical role in antigen-initiated PI hydrolysis and $\left[\mathrm{Ca}^{2+}\right]_{\mathrm{i}}$ elevation in Th cells. We conclude that 
the TCR/CD3 complex transduces at least two distinct signals, one which is a CD4-dependent complete signal and another that is a CD4-independent partial signal. The former signal is linked to PI hydrolysis, influx of $\mathrm{Ca}^{2+}$, and IL-2 mRNA induction; and the latter is linked to IL-2R mRNA induction but does not involve PI hydrolysis.

\section{Methods}

Antibodies. Mabs to CD4 (Leu3a; IgG1) and to CD3 (Leu4; IgG1) were kindly provided by Dr. Soo Young Yang (Sloan-Kettering Institute, New York). OKT4 (IgG2b) and OKT4A (IgG2a) were gifts from Dr. Patricia Rao (Ortho Diagnostic Systems, Inc., Raritan, NJ). Anti-CD2 MAbs 9-1 (IgG3) and 9.6 (IgG2a) were gifts from Dr. Paul Martin (Fred Hutchinson Cancer Center, Seattle, WA) (20).

Preparation of Fab fragments of Leu3a antibody. Fab fragments were cleaved from Leu3a antibody by incubating with papain (Pierce Chemical Co., Rockford, IL) for $8 \mathrm{~h}$ at $37^{\circ} \mathrm{C}$. Fab fragments were separated from $\mathrm{Fc}$ fragments by passing the antibody through a protein $\mathrm{A}$ column (Pierce Chemical Co.) and the purity was determined by SDSPAGE. Protein concentrations were determined using bicinchoninic acid (BCA kit; Pierce Chemical Co.) according to the manufacturer's protocol.

Reagents. PMA and cycloheximide (CHX) were purchased from Sigma Chemical Co., St. Louis, MO. The calcium ionophore, ionomycin, was obtained from Calbio-chem Behring Corp., La Jolla, CA. Recombinant human IL-1 $\alpha$ (rIL-1 $\alpha$ ), rIL-2, and rIL-6 were purchased from Genzyme Corp., Boston, MA.

Cells. Antigen-specific $\mathrm{T}$ cell clones specific for tetanus toxoid ( $\mathrm{Tt}$ ) and for purified protein derivative (PPD) were developed from peripheral blood of healthy donors and characterized as described previously $(21,22)$. Irradiated autologous Epstein-Barr virus (EBV)-transformed $B$ cells were used as APC. Cloned Th cells were maintained with irradiated APC by 5-d stimulation with antigen, followed by 10-d rest in the absence of antigen. After a resting period, viable $T$ cells were enriched by Ficoll-Hypaque density gradient centrifugation. Autologous EBV-transformed B cells were maintained separately, washed, irradiated (3,000 rads), and added to the Th cells in 1:1 ratio at the time of initiation of experiments. Clones used in this study, Tt1.3, PPD3.5, and $\mathrm{Tt} 4.2$, express the phenotype $\mathrm{CD}^{+} / \mathrm{CD}^{+} / \mathrm{CD} 45 \mathrm{RO}$ (UCHL1) ${ }^{+}$. These clones do not require addition of exogenous IL-2 and can proliferate and secrete IL-2 upon stimulation with antigen in the presence of APC, designated EBV 100 for Tt1.3, EBV300 for PPD3.5, and EBV400 for Tt4.2. Addition of anti-HLA DR MAb abrogates their responses.

Human peripheral blood mononuclear cells (PBMC) were isolated from heparinized venous blood of healthy donors by Ficoll-Hypaque density gradient centrifugation. Erythrocyte-rosetting $T$ cells were separated from nonrosetting cells by overnight rosette formation with neuraminidase-treated sheep red blood cells (SRBC), followed by FicollHypaque density gradient centrifugation. After lysis of rosetted SRBC, $T$ cells from the pellet were further depleted of contaminating monocytes by two cycles of plastic Petri dish adherence. These nonadherent cells were $>97 \%$ CD2-positive, and contained $<1 \%$ esterase-positive cells.

Cell cultures. RPMI 1640 (Gibco Laboratories, Grand Island, NY) supplemented with $10 \%$ heat-inactivated FCS (Gibco Laboratories), 2 mM L-glutamine (Whittaker Bioproducts, Inc., Walkersville, MD), $100 \mathrm{U} / \mathrm{ml}$ penicillin $\mathrm{G}$, and $100 \mu \mathrm{g} / \mathrm{ml}$ streptomycin was used for all cultures.

Antibody mediated cross-linking of CD4 by itself is known to trigger signal transduction and some biologic effects $(13,23)$. To minimize the CD4/CD4 cross-linking triggered effects, T cells were first precultured with anti-CD4 MAbs in the absence of APC followed by extensive washing before the addition of stimuli and APC. Anti-CD4 MAb treatment was carried out at $4^{\circ} \mathrm{C}$ for $16 \mathrm{~h}$ unless otherwise noted. In some experiments, anti-CD4 MAbs were cultured with soluble CD4 (sCD4; American Biotechnologies, Cambridge, MA) for $2 \mathrm{~h}$ at $4^{\circ} \mathrm{C}$ before the addition of $T$ cells. Thereafter, cells were washed and recultured with one of the following: medium alone, $\mathrm{Tt}(2 \mu \mathrm{g} / \mathrm{ml}), \operatorname{PPD}(2$ $\mu \mathrm{g} / \mathrm{ml}$ ), 1:1,000 dilution of MAbs to CD2 (a combination of 9.6 and 9-1), Leu4 (1 $\mu \mathrm{g} / \mathrm{ml})$, Leu4 plus PMA (10 ng/ml), PMA (10 ng/ml), PMA $(10 \mathrm{ng} / \mathrm{ml})$ plus ionomycin $(1 \mu \mathrm{M})$. The clone cell cultures were performed in the presence of APC. In selected experiments, CHX (10 $\mu \mathrm{g} / \mathrm{ml}$ ) was added $3 \mathrm{~h}$ after stimulation. These cells and culture supernatants were used for proliferation assays, Northern blot analysis, slotblot analysis, cell surface immunofluorescence studies, and for quantifying cytokine secretion.

Lymphocyte proliferation. Assays for lymphocyte proliferation were performed by culturing $1 \times 10^{4} \mathrm{~T}$ cells with $4 \times 10^{4} \mathrm{APC}$ in $0.2 \mathrm{ml}$ of complete medium in round-bottomed 96-well plates (Corning Glass, Inc., Corning, NY) with indicated stimuli for $48 \mathrm{~h}$, followed by a 16-h pulse of $1 \mu \mathrm{Ci}$ of $\left[{ }^{14} \mathrm{C}\right]$ thymidine (TdR). $\left[{ }^{14} \mathrm{C}\right] \mathrm{TdR}$ incorporation was measured in a liquid scintillation counter (Packard Instrument Co., Sterling, VA). All data are expressed as the mean cpm of triplicate determinations.

Isolation and characterization of $m R N A$. Total cellular RNA was obtained after lysis of $10 \times 10^{6}$ cells that had been cultured for $6 \mathrm{~h}$ at conditions indicated above with RNAzol (Cinna/Biotex, Friendswood, TX) according to the manufacturer's protocol. RNA for Northern blot analysis was denatured with formaldehyde, fractioned on a $6 \%$ formaldehyde/1.2\% agarose gel, and transferred to nylon membranes $(\mathrm{Ny}-$ tran, Schleicher \& Schuell, Inc., Keene, NH). RNA for slot-blot analysis was denatured with formaldehyde and applied to nylon membranes by using a "Hybri-slot" manifold (Bethesda Research Laboratories, Gaithersburg, MD) at $1 \mu \mathrm{g}$ per slot. RNA were quantitated by absorbance at $260 \mathrm{~nm}$ and purity was confirmed by $A_{260} / A 280_{280}$ ratios, which was $>1.8$ for all samples. Hybridization was performed overnight at $42^{\circ} \mathrm{C}$ in the presence of formamide with ${ }^{32} \mathrm{P}$-labeled DNA probes for IL-2 (24), IL-2R (25), $\beta$-actin (26), and 28S ribosomal RNA (27), respectively. Autoradiograms were produced and analyzed by using the Ultrscan XL laser densitometer (LKB Instruments, Inc., Gaithersburg, MD). After each hybridization, RNA blots were stripped of ${ }^{32} \mathrm{P}$-labeled probe by incubation at $72^{\circ} \mathrm{C}$ for $1 \mathrm{~h}$ in $2.5 \mathrm{mM}$ Tris- $\mathrm{HCl}$, pH 8.0, $0.1 \mathrm{mM}$ EDTA, and $0.5 \mathrm{mM}$ sodium pyrophosphate.

Flow cytometric analysis. For flow cytometric analysis, cells (1 $\times 10^{6} / \mathrm{ml}$ ) were stained with fluorescein-conjugated MAbs for $30 \mathrm{~min}$ at $4^{\circ} \mathrm{C}$ and washed twice with PBS. The washed cells were analyzed on a flow cytometer (Epics C, Coulter Electronics, Inc., Hialeah, FL). The MAbs used in these studies are: FITC-anti-CD25, (Becton, Dickinson, \& Co., Mountain View, CA), FITC-Leu3a (Becton, Dickinson, \& Co.), FITC-OKT4 (Ortho Diagnostic Systems, Inc.), and FITC-anti-CD3 (Coulter Electronics, Inc.).

Quantitation of cytokine production. Cells were cultured with or without stimuli for indicated periods, and cytokine content was assayed in culture supernatants. IL- $1 \alpha$ production was determined by using a radioimmunoassay (RIA) kit (Genzyme Corp.). ELISA kits were used for the quantification of IL-2 (Genzyme Corp.), IL-6 (Genzyme Corp.), and tumor necrosis factor- $\alpha$ (TNF $\alpha$-R\&D Systems, Inc., Minneapolis, MN).

Measurement of IP accumulation. Hydrolysis of phosphatidylinositides was determined as described (1). Briefly, cloned Th cells were labeled with $20 \mu \mathrm{Ci} / \mathrm{ml} m y o-2\left[{ }^{3} \mathrm{H}\right]$ inositol (New England Nuclear, Boston, MA) for $16 \mathrm{~h}$, washed, and resuspended in buffer containing 10 $\mathrm{mM} /$ liter $\mathrm{LiCl}$. Thereafter, cells were preincubated with Leu3a or medium alone for $30 \mathrm{~min}$ at $37^{\circ} \mathrm{C}$. Reactions were initiated by addition of APC and tetanus-antigen, and terminated after $10 \mathrm{~min}$ by the addition of $0.22 \mathrm{~N} \mathrm{HCl}$. Inositol metabolites were extracted with chloroform/ methanol 1:2 (vol/vol). Aquous phases, removed by addition of chloroform and water, were neutralized and applied to anion exchange columns Poly-Prep AG mesh (Bio-Rad Laboratories, Richmond, CA). Inositol monophosphate (IP), inositol diphosphate ( $\left.\mathrm{IP}_{2}\right)$, and inositol triphosphate $\left(\mathrm{IP}_{3}\right)$ were then sequentially eluted as described earlier (1). Total IPs were eluted with $0.1 \mathrm{M}$ formic acid/1.2 $\mathrm{M}$ ammonium formate. Radioactivity was assessed by liquid scintillation counting.

Measurement of intracellular calcium. $\left[\mathrm{Ca}^{2+}\right]_{\mathrm{i}}$ was measured ac- 
cording to the methods described (22) by using fluorescent indicator dye fluo-3. Briefly, Th cells $\left(1 \times 10^{6} / \mathrm{ml}\right)$ were precultured with Leu3a at $4^{\circ} \mathrm{C}$ for $2 \mathrm{~h}$. After washing. Th cells were loaded with $10 \mu \mathrm{M}$ fluo-3/ pentaacetoxymethyl (AM) ester (Molecular Probes, Inc., Eugene, OR) for $1 \mathrm{~h}$ in PBS at room temperature. Thereafter, Th cells were stimulated with antigen in the presence of APC. The fluorescence of the fluo-3/AM-loaded cells was monitored at excitation wavelength of 506 $\mathrm{nm}$, and emission wavelength of $526 \mathrm{~nm}$ on the flow cytometer. Maximal fluorescence was obtained by addition of $4 \mathrm{mM} \mathrm{CaCl}_{2}$ and minimum fluorescence by addition of $2 \mathrm{mM} \mathrm{MnCl}_{2}$. Intracellular calcium was calculated by the equation: $\left[\mathrm{Ca}^{2+}\right]_{\mathrm{i}}=K_{\mathrm{d}}\left[\left(F-F_{\min }\right) /\left(F_{\max }-F\right)\right]$, where $K_{\mathrm{d}}=450 \mathrm{nM}(22)$.

Paraformaldehyde (PFA) fixation of APC. In certain experiments, EBV 300 cells were cultured with PPD antigen $(2 \mu \mathrm{g} / \mathrm{ml})$ overnight at $37^{\circ} \mathrm{C}$ and then fixed with PFA. PFA fixation was performed by culturing $2 \times 10^{6} / \mathrm{ml}$ of EBV 300 in an equal volume of prewarmed $1 \%$ PFA in HBSS at $37^{\circ} \mathrm{C}$ for $7.5 \mathrm{~min}$, followed by four washes with HBSS

\section{Results}

Examination of the saturation dose of Leu3a for CD4. To elucidate the physiologic role of the CD4 molecule in antigen-initiated signal transduction in the class II MHC-restricted Th cells, we utilized two different anti-CD4 MAbs (Leu3a and OKT4) that recognize different epitopes on the CD4 molecule. The Leu3a-defined epitope, which maps in the V1 domain of the CD4 molecule, is critical for the interaction of CD4 with class II MHC molecules (28-31). In contrast, the OKT4-defined epitope, which is located outside the first two domains (31), is not considered to play a significant role in T cell activation in that some normal individuals lack this epitope (32). Fig. $1 A$ shows the saturation curve of CD4 on Th cells with various concentrations of Leu3a. $1 \mu \mathrm{g} / \mathrm{ml}$ of Leu3a blocked $>80 \%$ of the binding of fluorescein-conjugated Leu3a to Th cells. OKT4 expression, however, was the same in Leu3a-treated and medium-treated cells, suggesting that the CD4 molecule was not down-modulated by this treatment. In preliminary experiments, treatment of $T$ cells with anti-CD4 MAbs for varying time intervals at $4^{\circ} \mathrm{C}$ showed that a 2 -h pulse is sufficient to induce appropriate MAb-CD4 binding, and that pulsing up to $16 \mathrm{~h}$ does not induce down-modulation of $\mathrm{CD} 4$ nor of $\mathrm{CD} 3$ from the surface (data not shown).

Leu3a inhibits TCR/CD3-triggered lymphoproliferation, $I L-2$ secretion, and surface $I L-2 R$ expression. As shown in Table I, preincubation of the clone Tt 1.3 with Leu $3 a$ inhibited the proliferative response of the clone either to the tetanus antigen or to anti-CD3. In the dose-response study, the inhibition of proliferative response by Leu3a is well correlated to the occupancy of the CD4 molecules (Fig. 1 B). In agreement with previous reports (15), OKT4 was minimally inhibitory for the proliferative response. Proliferative responses elicited by antiCD2 or PMA plus ionomycin were not inhibited by Leu3a. Pretreatment of the T cell clone with $1 \mu \mathrm{g} / \mathrm{ml}$ Leu3a, but not OKT4, inhibited IL-2 secretion after antigenenic stimulation (Table I). Secretion of IL-2 induced by PMA plus ionomycin was not inhibited by Leu3a. The anti-CD4 MAbs did not by themselves cause lymphocyte proliferation. Although Leu3a pretreatment was carried out at $4^{\circ} \mathrm{C}$ in the absence of APC, there is still a possibility that after the cells are warmed and exposed to APC some CD4 cross-linking occurs, which is known to induce signals in $T$ cells $(13,23)$. To address this possibility, we examined the effects of Fab fragments of Leu3a on $\mathrm{T}$ cells. As shown in Table II. Fab fragments of Leu3a also
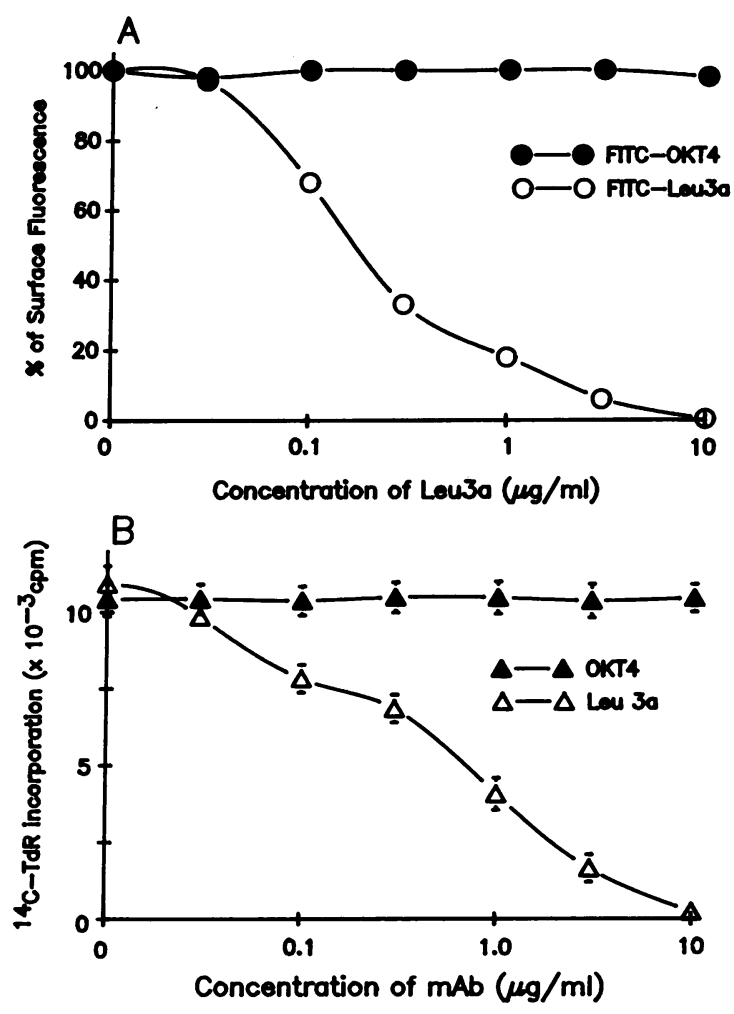

Figure 1. (A) Dose response of Leu3a binding to CD4. Cells from the Th clone $\mathrm{Tt} 1.3\left(1 \times 10^{6} / \mathrm{ml}\right)$ were incubated with medium or various concentrations of Leu3a for $2 \mathrm{~h}$ at $4^{\circ} \mathrm{C}$, washed, and analyzed for binding of FITC-conjugated Leu3a or OKT4 by flow cytometry. Values denote percentage of Leu3a and OKT4 binding of Leu3a-treated samples compared to medium-treated control. $(B)$ Leu3a inhibits antigen-specific proliferative responses of Th cells in a dose-dependent manner. Tetanus toxoid-specific cloned $T$ cells (Tt1.3) were pretreated with various concentrations of Leu3a or OKT4, respectively, and cultured for $2 \mathrm{~d}$ in the presence of tetanus antigen $(2 \mu \mathrm{g} / \mathrm{ml})$ and APC (EBV100), followed by $16 \mathrm{~h}$ pulse of $1 \mu \mathrm{Ci}$ of $\left[{ }^{14} \mathrm{C}\right] \mathrm{TdR}$.

inhibited the antigen-induced proliferative response of $\mathrm{T}$ cells. In contrast, Fc fragments of Leu3a had no inhibitory effects (data not shown). The degree of inhibition by Fab fragments was relatively less compared to whole IgG Leu3a. This is probably because monovalent antibody interferes with CD4-ligand interaction to a lesser degree, and/or because it is possible that whole IgG Leu3a-mediated cross-linking of CD4 also contributes to the observed inhibition. To ensure that the inhibitory effects of Leu3a were not due to some contamination in the preparation, we carried out a blocking study utilizing sCD4. As shown in Table III, addition of sCD4 dose-dependently abrogated the inhibitory effects of Leu3a. Moreover, OKT4A MAb, which is of the IgG2a subclass and binds to the V1 domain of CD4, was equally inhibitory for the antigen-induced proliferative response, and this inhibition was also abrogated by SCD4 treatment. We conclude therefore that the inhibitory effects of Leu3a and OKT4A can be attributed to CD4 molecule binding and is not related to their IgG subclass.

As shown in Fig. 2, pretreatment of the Th cells with 1 $\mu \mathrm{g} / \mathrm{ml}$ Leu3a clearly inhibited surface IL-2R expression after antigenic stimulation. OKT4 had no inhibitory effect on IL-2R expression. Induction of surface IL-2R expression elicited by anti-CD3 MAb was similarly inhibited; in contrast, anti-CD2 
Table I. Inhibition of TCR/CD3-initiated Proliferative Responses and IL-2 Secretion by Leu3a

\begin{tabular}{lccc}
\hline & \multicolumn{3}{c}{ Preincubation T Cells with* } \\
\cline { 2 - 4 } \multicolumn{1}{c}{ Stimulus } & Medium & Leu3a & OKT4 \\
\hline $\begin{array}{c}\text { Proliferative response } \\
\quad(\mathrm{cpm})^{\ddagger}\end{array}$ & & & \\
Medium & $458 \pm 64$ & $472 \pm 64$ & $427 \pm 86$ \\
Tetanus & $10,420 \pm 741$ & $4,060 \pm 521$ & $10,464 \pm 530$ \\
Anti-CD3 & $10,296 \pm 411$ & $3,826 \pm 740$ & $10,354 \pm 200$ \\
Anti-CD2 & $10,020 \pm 240$ & $10,826 \pm 241$ & $11,460 \pm 192$ \\
PMA+ ionomycin & $19,620 \pm 426$ & $19,700 \pm 200$ & $17,021 \pm 160$ \\
IL-2 secretion $(U / m)^{\S}$ & & & \\
Medium & $2.7 \pm 1.5$ & $3.0 \pm 1.4$ & $4.0 \pm 1.0$ \\
Tetanus & $79.0 \pm 12.6$ & $14.5 \pm 9.6$ & $68.7 \pm 13.3$ \\
PMA + ionomycin & $89.0 \pm 15.5$ & $93.5 \pm 23.3$ & $83.5 \pm 9.1$ \\
& & & \\
\hline
\end{tabular}

* Cells from clone Tt1.3 were precultured with medium, Leu3a (1 $\mu \mathrm{g} / \mathrm{ml})$, or OKT4 $(1 \mu \mathrm{g} / \mathrm{ml})$ at $4^{\circ} \mathrm{C}$ overnight. Stimuli were added in the presence of autologous APC (EBV100). ${ }^{*}$ Values denote mean and SD of triplicate cpm of $\left[{ }^{14} \mathrm{C}\right] \mathrm{TdR}$ incorporation. Results represent one of at least three experiments. ${ }^{8}$ Culture supernatants were collected at $24 \mathrm{~h}$, and were assayed for IL-2 by ELISA (Genzyme Corp.). Values denote mean of four independent experiments with SD.

MAb- or by PMA plus ionomycin-elicited IL-2R expression was not inhibited by Leu3a (data not shown).

Leu3a inhibits antigen-induced signal transduction events. An early event in $\mathrm{T}$ cell activation is the hydrolysis of phosphoinositides to water-soluble IPs, the IP turnover which in turn is closely linked to the regulation of $\left[\mathrm{Ca}^{2+}\right]_{i}$. Therefore, the effect of Leu3a on the accumulation of IPs and the increase in $\left[\mathrm{Ca}^{2+}\right]_{i}$ in antigen-stimulated $\mathrm{T}$ cell clones was examined. As shown in Fig. 3, the antigen-induced accumulation of IPs was inhibited if the Th cells were pretreated with Leu3a before antigenic stimulation. $1 \mu \mathrm{g} / \mathrm{ml}$ of Leu 3a completely inhibited the initial antigen-induced PI hydrolysis. Increase in antigen-in-

Table II. Comparison of Effect of Whole IgG and Fab Fragments of Leu3a on Antigen-induced Proliferative Response of T cells

\begin{tabular}{|c|c|c|}
\hline \multirow[b]{2}{*}{ Anti-CD4 MAb } & \multicolumn{2}{|c|}{ Preincubation of $T$ cells with* } \\
\hline & Leu3a & Fab Leu3a \\
\hline \multicolumn{3}{|c|}{$\left[{ }^{14} \mathrm{C}\right] \mathrm{TdR}$ incorporation } \\
\hline$\mu g / m l$ & \multicolumn{2}{|c|}{ cpm $(\% \text { inhibition })^{\ddagger}$} \\
\hline 0 & $14,698 \pm 732$ & $14,662 \pm 648$ \\
\hline 0.1 & $14,060 \pm 731(5)$ & $14,426 \pm 687(1)$ \\
\hline 0.5 & $10.097 \pm 1,141(31)$ & $13,827 \pm 773(6)$ \\
\hline 1.0 & $6,834 \pm 1,681(54)$ & $13,757 \pm 683(7)$ \\
\hline 5.0 & $5,624 \pm 753(63)$ & $9,236 \pm 1,172(38)$ \\
\hline
\end{tabular}

* $\mathrm{T}$ cells from clone $\mathrm{Tt} 4.2$ were precultured with various concentrations of whole IgG form of Leu3a or Fab fragments of Leu3a at $4^{\circ} \mathrm{C}$ for $16 \mathrm{~h}$. T cells were stimulated with $2 \mu \mathrm{g} / \mathrm{ml}$ of tetanus antigen in the presence of APC (EBV400). ${ }^{\ddagger}$ Values denote mean and SD of triplicate cpm of $\left[{ }^{14} \mathrm{C}\right] \mathrm{TdR}$ incorporation. Values in parentheses denote percent inhibition mediated by anti-CD4 MAbs as compared to responses obtained without anti-CD4 MAb treatment.
Table III. Soluble CD4 Reverses the Inhibitory Effects of AntiCD4 MAbs on Antigen-induced Proliferative Response of T cells

\begin{tabular}{|c|c|c|}
\hline \multirow{2}{*}{$\begin{array}{l}\text { Addition of SCD4 } \\
\text { to anti-CD4 MAbs }\end{array}$} & \multicolumn{2}{|c|}{$T$ cells pretreated with* } \\
\hline & Leu3a $(1 \mu \mathrm{g} / \mathrm{ml})$ & OKT $4 \mathrm{~A}(1 \mu \mathrm{g} / \mathrm{ml})$ \\
\hline \multicolumn{3}{|c|}{$\left[{ }^{14} \mathrm{C}\right] \mathrm{TdR}$ incorporation of $\mathrm{T}$ cells } \\
\hline$\mu g / m l$ & \multicolumn{2}{|c|}{$\operatorname{cpm}(\% \text { inhibition })^{\ddagger}$} \\
\hline 0 & $6,872 \pm 1,120(54)$ & $7,060 \pm 845(52)$ \\
\hline 0.1 & $6,994 \pm 703(53)$ & $7,240 \pm 648(51)$ \\
\hline 0.5 & $7,119 \pm 423(52)$ & $7,116 \pm 1,196(52$ \\
\hline 1.0 & $9,921 \pm 431(33)$ & $10,201 \pm 438(31)$ \\
\hline 5.0 & $14,837 \pm 1,621(0)$ & $14,006 \pm 983(5)$ \\
\hline 10.0 & $14,662 \pm 791(0)$ & $14,826 \pm 1,723(0)$ \\
\hline
\end{tabular}

* $1 \mu \mathrm{g} / \mathrm{ml}$ of Leu3a or OKT4A were cocultured with various concentration of SCD4 at $4^{\circ} \mathrm{C}$ for $2 \mathrm{~h}$; thereafter $\mathrm{T}$ cells ( $\left.\mathrm{Tt} 4.2\right)$ were added to the plate and cultured for additional $16 \mathrm{~h}$ at $4^{\circ} \mathrm{C}$. T cells were stimulated with $2 \mu \mathrm{g} / \mathrm{ml}$ tetanus antigen and APC (EBV400). ${ }^{\ddagger} \mathrm{Val}-$ ues denote mean and SD of triplicate cpm of $\left[{ }^{14} \mathrm{C}\right] \mathrm{TdR}$ incorporation. Values in parentheses denote percent inhibition compared to antiCD4 MAb untreated control value of $14,645 \pm 241$ (cpm).

duced $\left[\mathrm{Ca}^{2+}\right]_{\mathrm{i}}$ was also suppressed by Leu3a in a dose-dependent manner with complete suppression occurring at a dose of $1 \mu \mathrm{g} / \mathrm{ml}$ (Fig. 4).

Leu3a inhibits TCR/CD3-triggered $M R N A$ accumulation for $I L-2$ but not for $I L-2 R$. To determine whether antigen-induced IL-2 and IL-2R gene expression was affected by Leu3a, Northern blot analysis was performed on total RNA extracted at $6 \mathrm{~h}$ after stimulation from $\mathrm{Tt} 1.3$ with and without pretreatment with Leu3a. Fig. $5 \mathrm{~A}$ shows that antigen-induced IL-2 mRNA accumulation in Leu3a-treated cells was markedly reduced (lane 4). In contrast, no significant change was observed

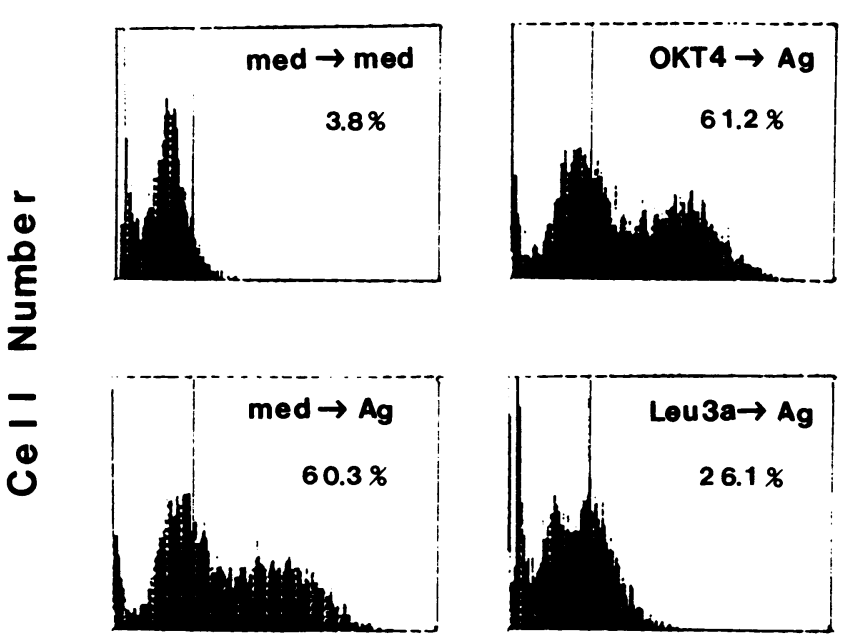

\section{Log Fluorescence Intensity}

Figure 2. Leu3a inhibits antigen-induced IL-2R expression on T cells. Cells (Tt4.2) were treated with medium, Leu3a $(1 \mu \mathrm{g} / \mathrm{ml})$, or OKT4 $(1 \mu \mathrm{g} / \mathrm{ml})$, respectively, washed, and cultured for $24 \mathrm{~h}$ with medium or tetanus antigen in the presence of APC (EBV400). The IL-2R expression was analyzed using FITC-conjugated anti-CD25 MAb. Values indicate the percentage of IL-2R-positive cells. 

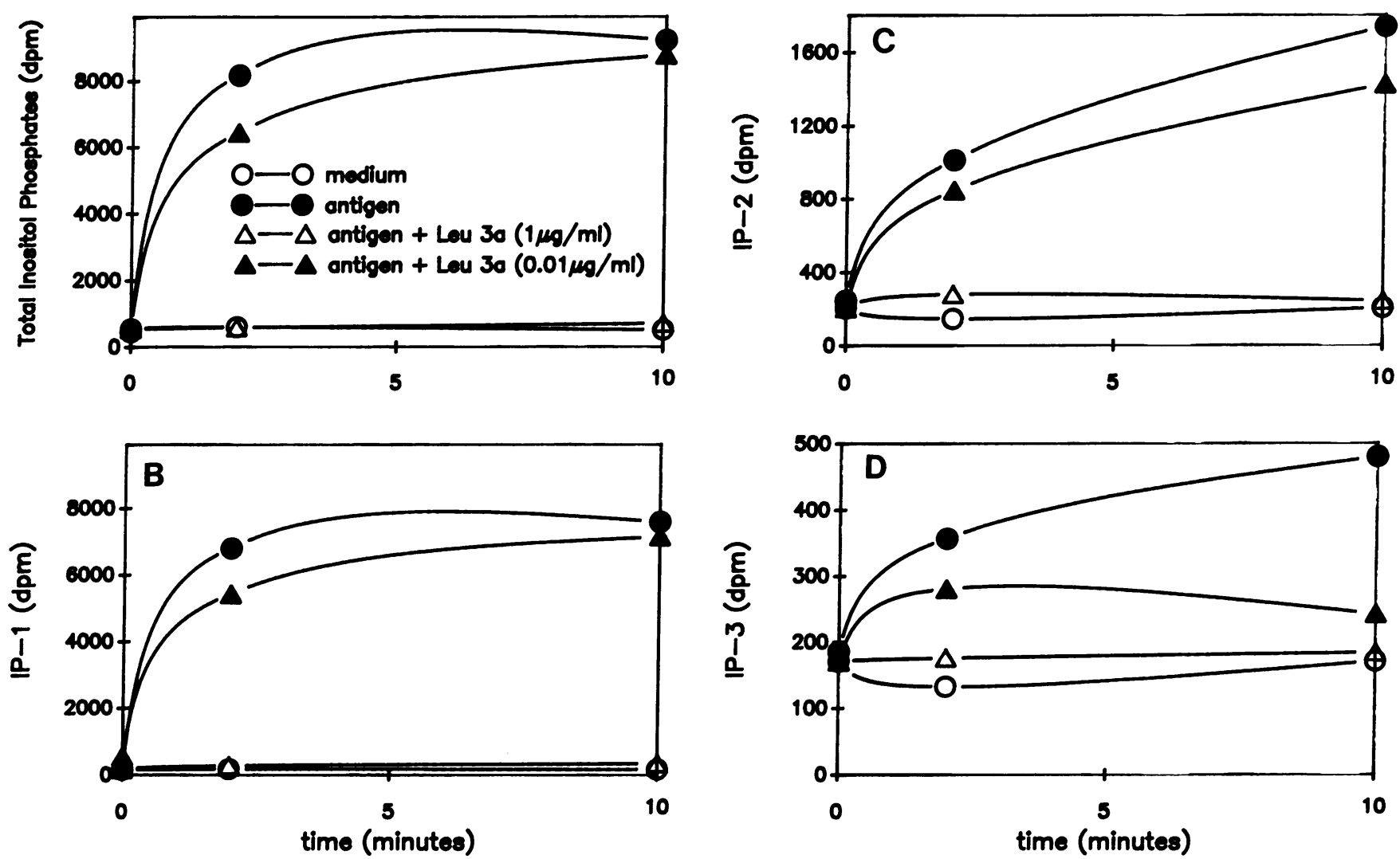

Figure 3. Leu3a inhibits accumulation of IPs. Cells from the Th clone $\mathrm{Tt} 1.3$ were labeled with $m y 0-2\left[{ }^{3} \mathrm{H}\right]$ inositol for $16 \mathrm{~h}$, and thereafter preincubated with medium or Leu3a at indicated concentrations. Reactions were initiated by addition of tetanus antigen $2 \mu \mathrm{g} / \mathrm{ml}$ and APC (EBV100) Reactions were terminated at 0,2 , and $10 \mathrm{~min}$. (upper left) Total IPs, (lower left) inositol monophosphate (IP-1), (upper right) inositol diphosphate $(I P-2)$, and (lower right) inositol triphosphate $(I P-3)$ were determined after anion exchange chromatography.

in IL-2R transcript. Addition of Leu3a alone failed to induce IL-2 or IL-2R gene transcription (lane 2). With PMA plus ionomycin stimulation, neither the IL-2 nor IL-2R gene transcripts were inhibited by Leu3a (lanes 5 and 6 ). It has been suggested that mRNA accumulation, including lymphokine mRNA, is regulated at two levels: namely, transcriptional regulation by

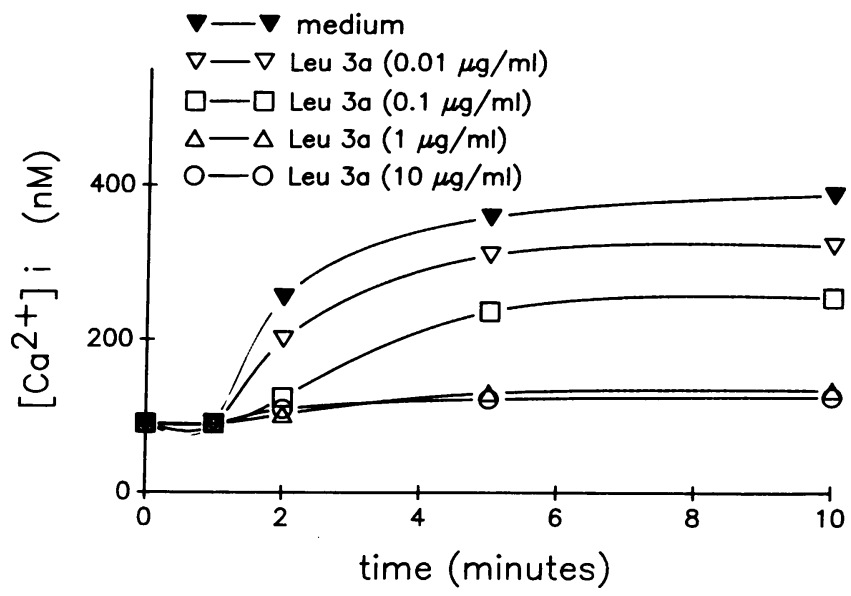

Figure 4. Leu3a inhibits antigen-induced increase of $\left[\mathrm{Ca}^{2+}\right]_{i}$ in a dose-dependent manner. Cells from Tt1.3 were pretreated with various concentrations of Leu3a as indicated. Increase in $\left[\mathrm{Ca}^{2+}\right]_{\mathrm{i}}$ levels after stimulation with tetanus antigen was assessed using fluorescent dye fluo-3/AM. elements acting on $5^{\prime}$ upstream gene sequence and posttranscriptional regulation by factors that influence mRNA stability acting over the $3^{\prime}$ untranslated region (33). To test whether the decrease in IL-2 mRNA levels could have resulted from a decreased rate of initiation of transcription or from enhanced degradation of the mRNA, CHX was added $3 \mathrm{~h}$ after the stimulation. $\mathrm{CHX}$ is known to inhibit the translation of proteins that lead to rapid degradation of IL-2 mRNA, thereby stabilizing the level of steady-state IL-2 mRNA (34). As shown in Fig. 5 B, CHX treatment resulted in increased IL-2 mRNA accumulation, but still the Leu3a-treated sample manifested a markedly decreased signal as compared to the untreated one (lane 10). These findings indicate that Leu3a affects the transcriptional rate of IL-2 gene, but does not affect its stability.

To determine whether the observation with $\mathrm{Tt} 1.3$ was peculiar to this particular clone or if it was representative of a more general phenomenon, the effect of Leu3a was examined in a PPD-specific Th clone, PPD3.5, established from another individual. Experiments performed with identical amounts (1 $\mu \mathrm{g}$ per slot) of RNA extracted from PPD3.5, as from Tt 1.3, indicated that Leu3a treatment inhibited PPD-antigen induced IL-2 mRNA accumulation, but not IL-2R mRNA, with or without addition of $\mathrm{CHX}$ (Fig. 6). The percent inhibition of IL-2 mRNA accumulation by Leu3a was $78 \%$ without CHX and $70 \%$ with $\mathrm{CHX}$, determined by densitometric analysis. IL$2 \mathrm{R}$ and $\beta$-actin mRNA accumulation were not affected by Leu3a regardless of the $\mathrm{CHX}$ treatment.

Next, we examined the effects of Leu3a on anti-CD3 MAb 


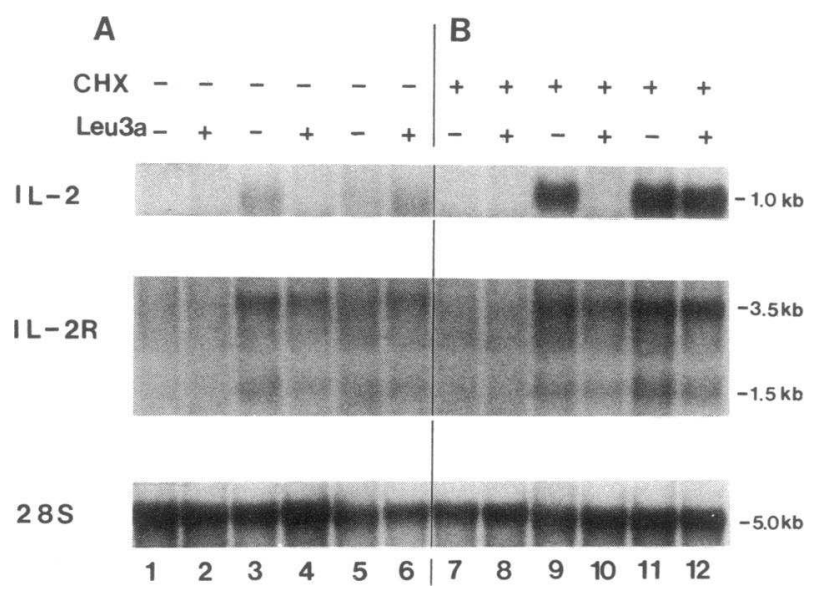

Figure 5. Effect of Leu3a on the induction of IL-2, IL-2R mRNA, and $28 \mathrm{~S}$ ribosomal RNA in T cell clone $\mathrm{Tt} 1.3$ in the $(A)$ absence or in the $(B)$ presence of $\mathrm{CHX}$. Cells were precultured with or without 1 $\mu \mathrm{g} / \mathrm{ml}$ of Leu3a and recultured with medium (lanes 1,2 and 7,8 ), tetanus antigen $2 \mu \mathrm{g} / \mathrm{ml}$ (lanes 3,4 and 9, 10), or PMA $10 \mathrm{ng} / \mathrm{ml} \mathrm{plus}$ ionomycin $1 \mu \mathrm{M}$ (lanes 5,6 and 11,12 ), respectively, in the presence of APC (EBV 100). CHX $(10 \mu \mathrm{g} / \mathrm{ml})$ were added to some cultures $3 \mathrm{~h}$ after stimulation (lanes 7-12). After a 6-h stimulation, total RNA was extracted and analyzed by Northern blotting. Each lane contains total RNA from $10 \times 10^{6}$ cells. The same filter was used for all hybridizations.

(Leu4)-mediated IL-2 and IL-2R mRNA accumulation in PBMC (Fig. 7). Although anti-CD3 Mab stimulates PBMC to proliferate, IL-2 mRNA was barely detected at $6 \mathrm{~h}$ in cultures stimulated with anti-CD3 alone (lanes 6-8). To obtain substantial amounts of IL-2 mRNA accumulation in PBMC at this culture period, a combination of PMA and anti-CD3 MAb was required (lanes 2-5). Leu3a, $1 \mu \mathrm{g} / \mathrm{ml}$, was found to inhibit anti-CD3 plus PMA-induced IL-2 mRNA gene transcription in PBMC (lane 3). For the induction of IL-2R mRNA, anti-CD3 MAb alone was sufficient (lanes 6-8) and it could not be substantially enhanced by PMA (lanes 2-5), even though PMA alone was a potent inducer for IL-2R mRNA. Leu3a did not inhibit the accumulation of IL-2R mRNA elicited by either anti-CD3 MAb or anti-CD3 MAb plus PMA.

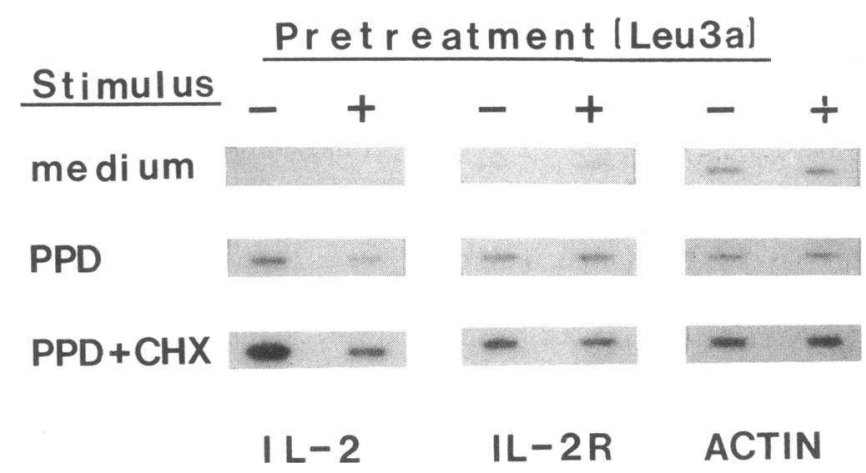

Figure 6. Slot-blot analysis for the detection of IL-2, IL-2R, and $\beta$ actin mRNA from T-cell clone PPD3.5. Cells were pretreated with

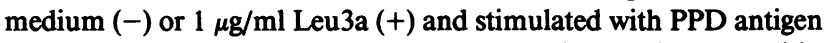
$(2 \mu \mathrm{g} / \mathrm{ml})$ in the presence of APC (EBV300) with or without addition of CHX $3 \mathrm{~h}$ after stimulation. Total RNA were extracted $6 \mathrm{~h}$ after stimulation. Each slot contained $1 \mu \mathrm{g}$ of total RNA.
PMA plus ionomycin-induced IL-2 and IL-2R mRNA accumulation were also not inhibited by Leu3a (lanes 9-11).

Shown in Fig. 8 is the effect of CHX on Leu3a-treated PBMC culture stimulated with anti-CD3 plus PMA. Treatment of PBMC with Leu3a resulted in inhibition of anti-CD3 plus PMA-induced IL-2 mRNA accumulation in PBMC regardless of the treatment with $\mathrm{CHX}$ (lanes 4 and 6). The percent inhibition by Leu3a in PBMC was less $(60 \%$ without CHX, lanes 3 and 4; 50\% with $\mathrm{CHX}$, lanes 5 and 6 ) compared to that in the Th clone; this difference is probably because PBMC are composed of a mixed cell population and the $T$ cell clones consist exclusively of $\mathrm{CD}^{+} \mathrm{T}$ cells.

Quantification of cytokines and their effect on $I L-2 R \mathrm{mRNA}$ induction. Because of the observed dichotomy between effects of Leu3a on IL-2R mRNA (which was normal) and surface expression (which was reduced) and also because we were using an APC-dependent culture system, the possibility was entertained that cytokines could have been released from the APC and influenced the $T$ cell activation responses, including IL-2R mRNA induction. To ensure that the IL-2R mRNA was not being up-regulated by cytokines released in culture, we performed three sets of experiments. First, we quantified IL- $1 \alpha$, IL-2, IL-6, and TNF $\alpha$, which are cytokines known to influence $T$ cell activation including the up-regulation of IL-2R (35-38), in the culture supernatants of Tt 1.3 and EBV 100. At $6 \mathrm{~h}$ after antigenic stimulation, which was the culture period utilized for Northern blot analysis, these cytokines were undetectable (IL$1 \alpha ;<80 \mathrm{pg} / \mathrm{ml}$; IL-2 $<1 \mathrm{U} / \mathrm{ml}$; IL-6 $<0.15 \mathrm{ng} / \mathrm{ml}$ ) with the exception of TNF $\alpha$ of which low amounts $(52 \mathrm{pg} / \mathrm{ml})$ were detected. Next, the influence of exogenous addition of various factors on IL-2R expression in T cells was examined in the absence of APC. Because our cultures of T cell clones could not be maintained in the absence of APC, we used purified peripheral blood $\mathrm{T}$ cells for this purpose. Fig. 9 shows that PMA, ionomycin, IL-2, or combinations of PMA plus ionomycin upregulate IL-2R mRNA accumulation in $6 \mathrm{~h}$ (lanes 5-8). However, IL-2R mRNA accumulation was not up-regulated by recombinant IL- $1 \alpha$ at a dose range of $1-100 \mathrm{U} / \mathrm{ml}$ (lanes 2-4), recombinant IL-6 $10 \mathrm{U} / \mathrm{ml}$ (lane 9), or IL-6 plus IL- $1 \alpha 10 \mathrm{U} / \mathrm{ml}$ (lane 10). It is noteworthy that, although IL-2R mRNA up-regulation by PMA was comparable to that induced by PMA plus ionomycin, surface IL-2R expression, measured at $24 \mathrm{~h}$ in the same sample, was distinctly less: the percentage of IL-2R-positive cells was $18 \%$ induced by PMA alone, $15 \%$ by ionomycin alone, and $44 \%$ by PMA plus ionomycin. Finally, we employed PFA-fixed APC, EBV300, for the induction of IL-2R mRNA in Th clone PPD3.5 (Fig. 10). We found that PPD antigen prepulsed PFA-fixed EBV300 did function as APC to induce IL-2R mRNA (lane 3) at a similar degree to unfixed cells (lane 4). In contrast, if the antigen was added to the culture after PFA fixation of EBV 300, IL-2R mRNA induction was no longer detectable (lane 2). These observations thus clearly rule out the participation of soluble factors released from APC in inducing IL-2R mRNA accumulation in our cell culture system.

\section{Discussion}

The CD4 molecule is known to play an essential role in T cell activation, but the extent of its participation in signal transduction that culminates in biologic $\mathrm{T}$ cell function are still unclear. In this study, we have examined the role of the CD4 molecule in effecting two major prerequisites of $T$ cell proliferation: IL-2 

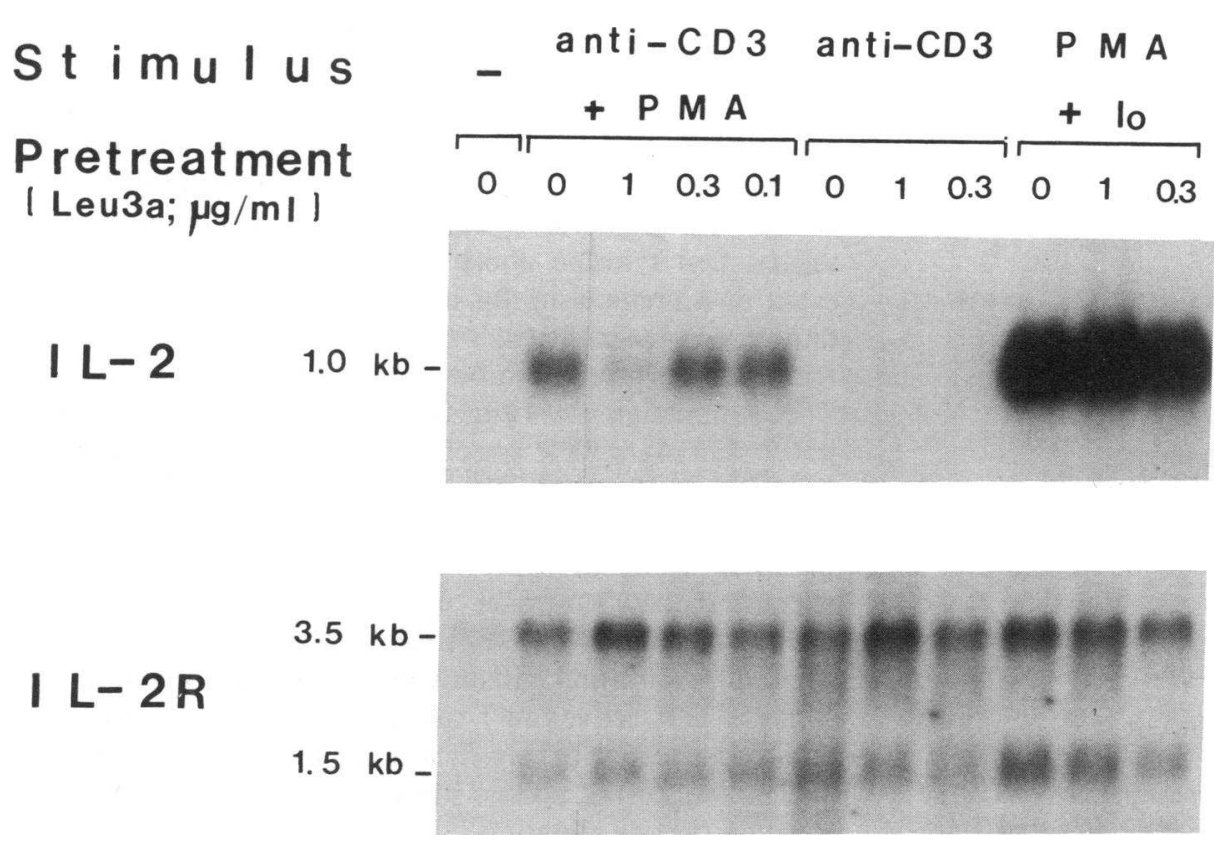

Figure 7. Effect of Leu3a on the induction of IL-2, IL-2R, and $\beta$-actin mRNA in PBMC. Cell were pretreated with medium or various concentrations of Leu3a as indicated, and stimulated for $6 \mathrm{~h}$ with medium (lane 1 ), Leu4 $1 \mu \mathrm{g} / \mathrm{ml}$ plus PMA $10 \mathrm{ng} / \mathrm{ml}$ (lanes 2-5), Leu4

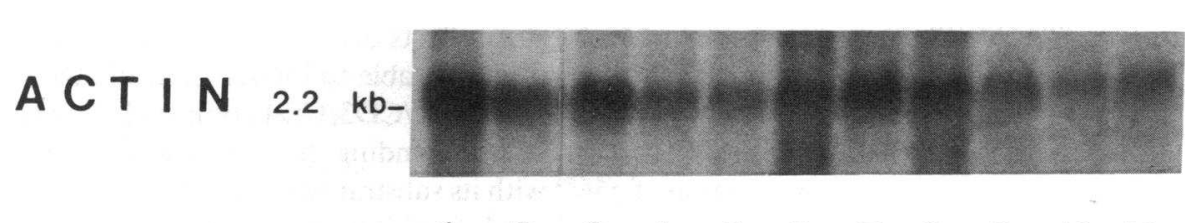

$\begin{array}{lllllllllll}1 & 2 & 3 & 4 & 5 & 6 & 7 & 8 & 9 & 10 & 11\end{array}$ alone (lanes 6-8), and PMA $10 \mathrm{ng} / \mathrm{ml}$ plus ionomycin (Io) $1 \mu \mathrm{M}$ (lanes 9-11). RNA samples were analyzed by gel electrophoresis and Northern blotting. Each track represents RNA from 1 $\times 10^{6}$ cells. The same filter was used for all hybridizations.

secretion and IL-2R expression. Utilizing two anti-CD4 MAbs recognizing distinct epitopes of CD4, we provide evidence indicating that the role of CD4 in TCR/CD3-mediated signal transduction involves PI hydrolysis and concomitant increases in $\left[\mathrm{Ca}^{2+}\right]_{\mathrm{i}}$ leading to induction of IL-2 and cell surface IL-2R expression. IL-2R mRNA induction subsequent to TCR/CD3
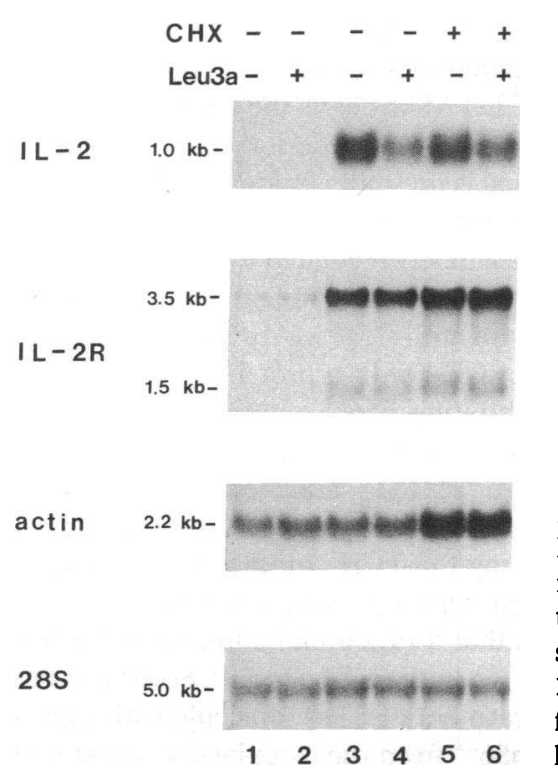

Figure 8. Effect of CHX on the induction of the IL-2, IL-2R, $\beta$-actin mRNA, and $28 \mathrm{~S}$ ribosomal RNA in PBMC Cells were pretreated with medium (-) or 1 $\mu \mathrm{g} / \mathrm{ml}$ of Leu3a and stimulated for $6 \mathrm{~h}$ with medium (lanes 1 and 2) or Leu4 $1 \mu \mathrm{g} / \mathrm{ml}$ plus PMA $10 \mathrm{ng} / \mathrm{ml}$ (lanes 3-6). CHX $10 \mu \mathrm{g} / \mathrm{ml}$ tures (lanes 5 and 6) 3 $h$ after stimulation. RNA samples were analyzed by gel electrophoresis and Northern blotting. Each track represents total RNA from 1 $\times 10^{6}$ cells. The same filter was used for all hybridizations. was added to some cul- activation, however, can occur without participation of the CD4 molecule and is independent of PI hydrolysis.

Activation of T cells by TCR/CD3 results in PI hydrolysis and mobilization of $\left[\mathrm{Ca}^{2+}\right]_{i}$. The accumulation of $\mathrm{IP}_{3}$ results in release of calcium from intracellular stores $(1,3)$ and possibly might also regulate transmembrane flux of calcium (39). Elevation of $\left[\mathrm{Ca}^{2+}\right]_{i}$ is deemed to be essential for induction of IL-2 $(40,41)$. The creation of physical proximity between CD3 and CD4 by cross-linking augments PI hydrolysis and $\left[\mathrm{Ca}^{2+}\right]_{\mathrm{i}}$ elevation in $T$ cells (42). Although this finding and the fact that anti-CD4 MAb inhibits antigen-induced $T$ cell activation imply that CD4 plays a critical role in the triggering of the inositol lipid pathway with consequent increase in $\left[\mathrm{Ca}^{2+}\right]_{i}$, the reported effect of anti-CD4 MAbs on TCR/CD3-mediated signal transduction are presently quite controversial. The only studies done so far have utilized nonphysiologic cell culture systems $(43,44)$ and have suggested that anti-CD4 MAb inhibits TCR/CD3-mediated $\left[\mathrm{Ca}^{2+}\right]_{\mathrm{i}}$ elevation without affecting PI hydrolysis. Rosoff et al. (43) reported that anti-CD4 MAbs inhibited antigen and Con A-stimulated $\mathrm{Ca}^{2+}$ influx in $\mathrm{T}$ cells without affecting PI hydrolysis. Tamura et al. (44) reported that anti-CD4 MAb blocked soluble anti-CD3-triggered elevation of $\left[\mathrm{Ca}^{2+}\right]_{i}$ in the absence of participation of PI hydrolysis. Both of these studies utilized highly unusual murine Th cells. The former (43) utilized a murine T cell hybridoma, which was unusual in that it secreted IL- 2 in response to a self MHC class I antigen, in the absence of self class II MHC restriction. The latter study (44) was performed with an alloractive Th clone, the biologic response of which was also apparently quite different from conventional antigen-specific Th cells in that these 

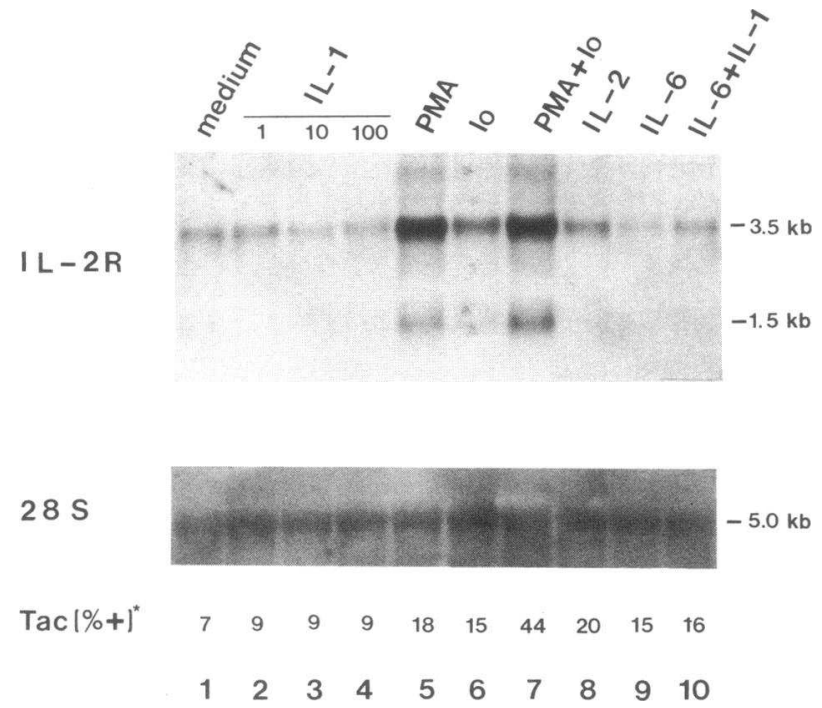

Figure 9. Effect of various stimuli on the induction of IL-2R mRNA from purified peripheral blood $T$ cells. Cells were cultured with medium (lane 1); recombinant IL- $1 \alpha$ at the concentrations of $1 \mathrm{U} / \mathrm{ml}$ (lane 2), $10 \mathrm{U} / \mathrm{ml}$ (lane 3), $100 \mathrm{U} / \mathrm{ml}$ (lane 4); PMA $10 \mathrm{ng} / \mathrm{ml}$ (lane 5); ionomycin (Io) $1 \mu \mathrm{M}$ (lane 6), combination of PMA and ionomycin (lane 7), $100 \mathrm{U} / \mathrm{ml}$ of rIL-2 (lane 8 ), $20 \mathrm{U} / \mathrm{ml}$ of rIL-6 (lane 9), or combination of rIL-6, $20 \mathrm{U} / \mathrm{ml}$, and rIL-1- $\alpha, 10 \mathrm{U} / \mathrm{ml}$ (lane 10 ), respectively. After a 6-h stimulation, total RNA were extracted and were analyzed by Northern blotting. Each lane contains total RNA from $10 \times 10^{6}$ cells. *Percentage of surface IL-2R (Tac, CD25)-positive cells, which was measured at $24 \mathrm{~h}$ from the identical samples, are indicated.

alloreactive Th clones could secrete IL-2 and proliferate in response to soluble anti-CD3 MAb in the absence of APC with little accumulation of IPs. In the data reported in the present study, we provide the first definitive evidence in a physiologic class II-restricted antigen-specific Th cell culture system that CD4 molecule participation is essential for both PI hydrolysis and increase in $\left[\mathrm{Ca}^{2+}\right]_{i}$.

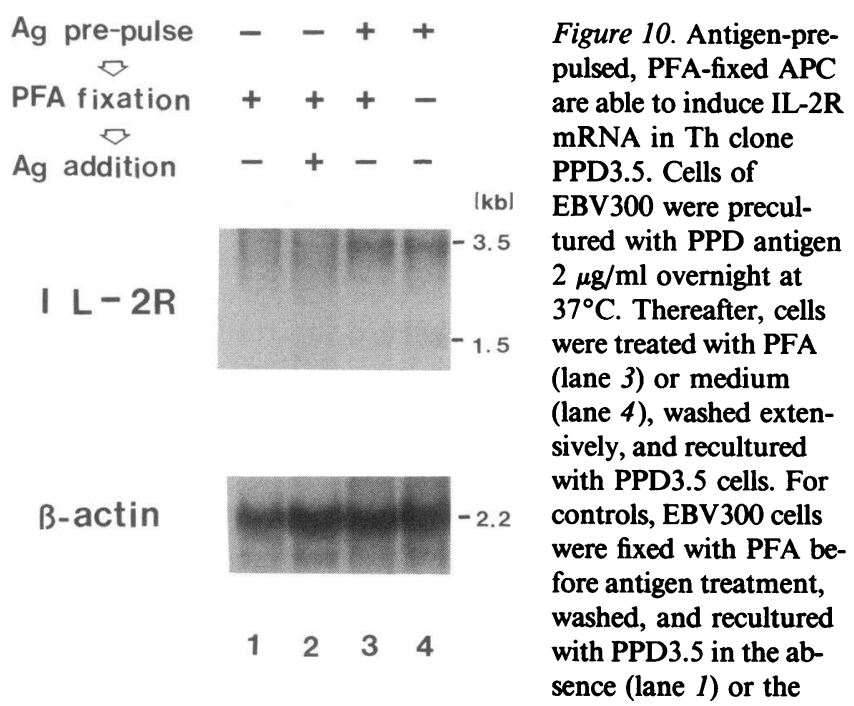

presence (lanes 2$)$ of PPD antigen $(2 \mu \mathrm{g} / \mathrm{ml})$. After a 6-h stimulation, total RNA was extracted and analyzed by Northern blotting. Each lane contains total RNA from $10 \times 10^{6}$ cells. The same filter was used for all hybridizations.
The mechanism for the inhibition of signal transduction by Leu 3a MAb in T cells is presently speculative. TCR activation by antigen has also been shown to stimulate protein tyrosine kinase (PTK) activity followed by increase in tyrosine phosphorylation of PLC- $\gamma 1$ (45) and TCR $-\zeta$ chain (46). Tyrosine phosphorylation of PLC- $\gamma 1$ results in increased PLC catalytic activity and activation of the IP pathway (47). Recent studies suggest that tyrosine phosphorylation may be a regulatory event or a prerequisite for inositol phospholipid breakdown during receptor-mediated $T$ cell activation $(48,49)$. However, the enzymatic machinery that leads to PLC- $\gamma 1$ activation upon TCR stimulation is undefined (50). Based on recent studies of p56 $6^{\text {lck }}(12-14)$, a PTK associated with the cytoplasmic tail of CD4, it seems likely that the external domain of CD4 binds the same MHC as the TCR, a step which brings lck into close proximity with $\mathrm{TCR} / \mathrm{CD} 3(10,11)$. As a result, $\mathrm{p} 56^{\text {lck }}$ might be exposed to new substrates and/or regulatory proteins in the vicinity of the TCR/CD3 complex, thereby facilitating tyrosine phosphorylation and initiating PI hydrolysis. Given the importance of TPK activity in T cell activation, the participation of CD4-associated $\mathrm{p} 56^{\text {lck }}$ is critical since TCR/CD3 complexes by themselves do not possess intrinsic TPK activity. Moreover, deletion (51) or mutation (52) of the cytoplasmic domain of CD4 that makes p56 $6^{\text {lck }}$ unable to bind CD4, results in failure of $T$ cell activation. Thus, the most likely explanation for the mechanism of inhibitory effects of Leu3a on antigen-initiated PI hydrolysis is that Leu3a is able to hinder sterically the formation of the functional TCR/CD3/CD4 complex by interfering with CD4-MHC class II binding that is needed for optimal interaction of $\mathrm{p} 56^{\text {lck }}$ with its substrate(s). The differential effects of OKT4 and Leu3a and the ability of Fab fragments of Leu3a to inhibit Th cell activation strongly supports this notion. Several other lines of evidence also support this contention. Synthetic peptides derived from HLA-DR and a peptide derived from V1 domain of CD4 were shown to inhibit antigen-induced HLA-DR-restricted T cell proliferation (53). It has also recently been shown that the ability of mutant CD4-expressing cells to form rosettes with class II MHC-expressing target cells paralleled their ability to support IL-2 secretion (54). In fact, Leu3a has been shown to block markedly CD4-class II MHC adhesion but OKT4 blocks this adhesion to a much less degree (30).

Another possibility is that Leu3a might induce negative regulatory signals through the CD4 molecule. Negative regulatory signaling by CD4 was originally proposed based on the observation that certain anti-CD4 MAbs have the ability to inhibit $T$ cell activation in the absence of accessory cells (15). The nature of the negative signal is presently unidentified; however, the following possibilities can be proposed. First, the fact that PTK activity of p $56^{\text {lck }}$ is negatively regulated by the phosphorylation of a carboxy-terminal tyrosine residue of p56 ${ }^{\text {lck }}$ (Tyr505) $(55,56)$ suggests that certain anti-CD4 MAbs might also interefere in the interaction of CD4 with a protein tyrosine phosphatase CD45, hence inhibiting p56 $6^{\text {lck }}$ activity. In mutant $T$ cell lines that do not express CD45 protein, stimulation of the TCR failed to elicit PI turnover (57). Transfection with cDNA for CD45 restored induction of PI turnover, indicating that CD45 is essential in linking the TCR complex to PI metabolism, presumably through dephosphorylation events. In fact, recent evidence suggests that a functional complex is formed between CD45 and p56 $6^{\text {lck }}$ in human T cells (58). Second, it has also been shown that treatment of CD4 molecule with Leu3a leads to dissociation of $\mathrm{p} 56^{\text {lck }}$ from the cytoplasmic domain of 
CD4 (59). This phenomenon might also account for anti-CD4 MAb-induced negative signal. These possibilities are currently under investigation in our laboratory.

The proliferative response in $\mathrm{T}$ cells is dependent upon the interaction of IL-2 with its specific receptors. These receptors comprise at least two distinct polypeptide chains: $\alpha$ chains (IL$2 \mathrm{R} \alpha$, Tac, CD25), which are expressed only after activation, and $\beta$ chains (IL-2R $\beta, \mathrm{p} 70-\mathrm{p} 75$ ), which are expressed on resting and activated $T$ cells (60). A major finding in this study is that antigen-induced IL-2R mRNA induction was unaffected by Leu3a even when it was used at the dose which completely inhibited the PI hydrolysis. Antigenic activation-induced upregulation of IL-2R mRNA was apparently not diminished by Leu3a, but cell surface levels of IL-2R were clearly decreased. In our test system we ruled out the possibility that IL-2R mRNA was being secondarily up-regulated by cytokines secreted from APC. Anti-CD4 MAb treatment by itself has also been reported to up-regulate IL-2R expression, but this was only observed after cross-linking of CD4 molecules (61). In fact, in our test system anti-CD4 treatment alone failed to induce IL-2R mRNA accumulation. The failure of membrane IL-2R expression despite accumulation of mRNA for IL-2R suggests that more than one activation signal is required for surface IL-2R expression. In support of this contention is the observation in human $\mathrm{T}$ cell subsets that IL-2 responsiveness (presumably, via induction of IL-2R expression) was induced in $\mathrm{CD}^{+} \mathrm{T}$ cells by either Con A, OKT3 MAb, PMA, or ionomycin, whereas neither of these stimuli was by itself sufficient for inducing IL-2 responsiveness in the purified $\mathrm{CD}^{+}$subset (62). The same was also observed in murine T cells (63). The dichotomy of IL-2R between mRNA levels and cell surface levels has also been observed in some $T$ cell culture systems utilizing immunosuppressive drugs such as cyclosporine A, FK-506, and dexamethasone (64-66). These drugs have been shown to inhibit mitogen- or anti-CD3-induced IL-2 mRNA expression, IL-2 secretion, surface IL-2R expression, but IL-2R mRNA induction was unaffected. In addition, cyclosporine $A$ and FK-506 have been shown to selectively inhibit $\mathrm{Ca}^{2+}$-associated events of early $T$ cell activation $(67,68)$. These observations and the dichotomy of IL-2R between mRNA levels and cell surface levels observed in the present study suggest that the PI pathway, particularly $\mathrm{Ca}^{2+}$-mediated signaling, is not required for IL-2R mRNA induction, but is involved in the expression of surface IL-2R at a posttranscriptional level.

In conclusion, our data provides evidence that the CD4 molecule plays a critical role in inducing IL-2 gene transcription and surface IL-2R expression through triggering TCR/ CD3 complex-mediated PI hydrolysis and increase in $\left[\mathrm{Ca}^{2+}\right]_{i}$. In contrast, the TCR/CD3 complex transduces CD4-independent signals which induce IL-2R mRNA transcription. The exact nature of this signal(s) is presently unknown. However, the recent reports that $(a)$ nuclear factor $\kappa \mathrm{B}$, a critical nuclear binding protein for the IL-2R gene transcription (69), is inducible in the absence of PKC activation (70) and $(b)$ a proposed mechanism of PKC activation by generating diacylglycerol from phosphatidylcholine in the absence of PI turnover (71), support the presence of such a mechanism. These observations provide insight into the signal transduction mechanisms during Th cell activation and also contribute to our understanding of the pathogenesis of HIV infection, in that we observed essentially the same phenomenon using HIV-1 envelope protein gp120, which shares the binding site on CD4 with Leu3a (19, $22)$. These findings warrant caution in considering HIV vac- cines that include the CD4-binding epitope of gp120/160 because of its immunosuppressive potential.

\section{Acknowledgments}

We thank Dr. Soo Young Yang (Sloan-Kettering Institute, New York) for Leu3a and Leu4; Dr. Patricia Rao (Ortho Diagnostic Systems, Inc., Raritan, NJ) for OKT4 and OKT4A; Dr. Paul Martin (Fred Hutchinson Cancer Center, Seattle, WA) for anti-CD2 MAbs (9-1, 9.6); and Ms. M. Marecki, Ms. C. Leombruno, and Ms. R. Pasieka for excellent technical support.

This work was supported by National Institutes of Health Grants $\mathrm{AI}-28281$ and DA-05161.

\section{References}

1. Imboden, J. B., and J. D. Stobo. 1985. Transmembrane signaling by the T cell antigen receptor: pertubation of the $\mathrm{T} 3$-antigen receptor complex generates inositol phosphates and releases calcium ions from intracellular stores. J. Exp. Med. 161:446-456.

2. Desai, D. M., M. E. Newton, T. Kadlecek, and A. Weiss. 1990. Stimulation of the phosphatidylinositol pathway can induce T-cell activation. Nature (Lond.). 348:66-69.

3. Isakov, N., M. I. Mally, W. Scholz, and A. Altman. 1987. T-lymphocyte activation: the role of protein kinase $\mathrm{C}$ and the bifurcating inositol phospholipid signal transduction pathway. Immunol. Rev. 95:89-112.

4. Marrack, P., R. Endres, R. Shimonkevitz, A. Zlotnik, D. Dialynas, F. Fitch, and J. Kappler. 1983. The major histocompatibility complex-restricted antigen receptor on T cells. II. Role of the L3T4 product. J. Exp. Med. 158:1077-1091.

5. Wilde, D. B., P. Marrack, J. Kappler, D. P. Dialynas, and F. W. Fitch. 1983. Evidence implicating L3T4 in class II MHC antigen reactivity: monoclonal antibody GK1.5 (anti-L3T4a) blocks class II MHC antigen-specific proliferation, release of lymphokines, and binding by cloned murine helper $\mathrm{T}$ lymphocyte lines. J. Immunol. 131:2178-2183.

6. Gay, D., P. Maddon, R. Sekaly, M. A. Talle, M. Godfrey, E. Long, G. Goldstein, L. Chess, R. Axel, J. Kappler, et al. 1987. Functional interaction between human T-cell protein CD4 and the major histocompatibility complex HLA-DR antigen. Nature (Lond.). 328:626-629.

7. Doyle, C., and J. L. Strominger. 1987. Interaction between CD4 and class II MHC molecules mediates cell adhesion. Nature (Lond.). 330:256-259.

8. Saizawa, K., J. Rojo, and C. A. Janeway, Jr. 1987. Evidence for a physical association of CD4 and CD3: $\alpha: \beta$ T-cell receptor. Nature (Lond.). 328:260-263.

9. Rivas, A., S. Takada, J. Koide, G. Sonderstrup-McDevitt, and E. G. Engleman. 1988. CD4 molecules are associated with the antigen receptor complex on activated but not resting T cells. J. Immunol. 140:2912-2918.

10. Mittler, R. S., S. J. Goldman, G. L. Spitalny, and S. J. Burakoff. 1989. $\mathrm{T}$-cell receptor-CD4 physical association in a murine T-cell hybridoma: induction by antigen receptor ligation. Proc. Natl. Acad. Sci. USA. 86:8531-8535.

11. Gallagher, P. F., B. Fazekas De St. Groth, and J. F. A. P. Miller. 1989. CD4 and CD8 molecules can physically associate with the same T-cell receptor. Proc. Natl. Acad. Sci. USA. 86:10044-10048.

12. Rudd, C. E., J. M. Trevillyan, J. D. Dasgupta, L. L. Wong, and S. F. Schlossman. 1988. The CD4 receptor is complexed in detergent lysates to protein-tyrosine kinase (pp58) from human T lymphocytes. Proc. Natl. Acad. Sci. USA. 85:5190-5194.

13. Veillette, A., M. A. Bookman, E. M. Horak, L. E. Samelson, and J. B. Bolen. 1989. Signal transduction through the CD4 receptor involves the activation of the internal membrane tyrosine-protein kinase p56lck. Nature (Lond.). 338:257-259.

14. Rudd, C. E. 1990. CD4, CD8 and the TCR-CD3 complex: a novel class of protein-tyrosine kinase. Immunol. Today. 11:400-406.

15. Bank, I., and L. Chess. 1985. Pertubation of the T4 molecule transmits a negative signal to T cells. J. Exp. Med. 162:1294-1303.

16. Bekoff, M., T. Kakiuchi, and H. M. Grey. 1985. Accessory cell function in the Con A response: role of Ia-positive and Ia-negative accessory cells. $\mathrm{J}$. Immunol. 134:1337-1342.

17. Wassmer, P., C. Chan, L. Lögdberg, and E. M. Shevach. 1985. Role of the L3T4-antigen in T cell activation. II. Inhibition of T cell activation by monoclonal anti-L3T4 antibodies in the absence of accessory cells. J. Immunol. 135:2237-2242.

18. Geppeart, T. D., P. E. Lipsky. 1987. Accessory cell independent proliferation of human T4 cells stimulated by immobilized monoclonal antibodies to CD3. J. Immunol. 138:1660-1666.

19. Oyaizu, N., N. Chirmule, V. S. Kalyanaraman, W. W. Hall, R. A. Good, and S. Pahwa. 1990. Human immunodeficiency virus type 1 envelope glycoprotein gp 120 produces immune defects in $\mathrm{CD4}^{+} \mathrm{T}$ lymphocytes by inhibiting interleukin 2 mRNA. Proc. Natl. Acad. Sci. USA. 87:2397-2383.

20. Yang, S. Y., S. Chouaib, and B. Dupont. 1986. A common pathway for T lymphocyte activation involving both the CD3-Ti complex and CD2 sheep erythrocyte receptor determinants. J. Immunol. 137:1097-1100. 
21. Volkman, D. J., L. A. Matis, and A. S. Fauci. 1984. Developement and characterization of interleukin independent antigen-specific human $\mathrm{T}$ cell clones that produce multiple lymphokines. Cell. Immunol. 88:323-335.

22. Chirmule, N., V.S. Kalyanaraman, N. Oyaizu, H. B. Slade, and S. Pahwa 1990. Inhibition of functional properties of tetanus antigen-specific T-cell clones by envelope glycoprotein gp120 of human immunodeficiency virus. Blood. 75:152-159.

23. Veillette, A., J. B. Bolen, and M. A. Bookman. 1989. Alternations in tyrosine protein phosphorylation induced by antibody-mediated cross-linking of the CD4 receptor of T lymphocytes. Mol. Cell. Biol. 9:4441-4446.

24. Devos, R., G. Plaetinck, H. Cheroutre, G. Simons, W. Degrave, J. T. Remaut, and W. Fiers. 1983. Molecular cloning of human interleukin $2 \mathrm{cDNA}$ and its expression in E. coli. Nucleic Acids Res. 11:4307-4323.

25. Leonard, W. J., J. M. Depper, G. R. Crabtree, S. Rudikoff, J. Pumphrey, R. J. Robb, M. Krönke, P. B. Svetlik, N. J. Peffer, T. A. Waldmann, et al. 1984. Molecular cloning and expression of cDNAs for the human interleukin-2 receptor. Nature (Lond.). 311:626-631.

26. Spiegelman, B. M., M. Frank, and H. Green. 1983. Molecular cloning of mRNA from 3T3 adipocytes. J. Biol. Chem. 258:10083-10089.

27. Bowman, L. H., W. E. Goldman, G. I. Goldberg, M. B. Hebert, and D. Schlessinger. 1983. Location of the initial cleavage sites in mouse pre-rRNA. Mol. Cell. Biol. 3:1488-1500.

28. Peterson, A., and B. Seed. 1988. Genetic analysis of monoclonal antibody and HIV binding sites on human lymphocyte antigen CD4. Cell. 54:65-72.

29. Clayton, L. K., M. Sieh, D. A. Pious, and E. L. Reinherz. 1989. Identification of human CD4 residues affecting class II MHC versus HIV-1 gp 120 binding. Nature (Lond.). 339:548-551.

30. Rosenstein, Y., S. J. Burakoff, and S. H. Herrmann. 1990. HIV-gp1 20 can block CD4-class II MHC-mediated adhesion. J. Immunol. 144:526-531

31. Landau, N. R., M. Warton, and D. R. Littman. 1988. The envelope glycoprotein of the human immunodeficiency virus binds to the immunoglobulin-like domain of CD4. Nature (Lond.). 334:159-162.

32. Pahwa, S., C. Sia, C. Te, R. Harper, and R. Pahwa. 1985. Ethnic heterogeneity in the distribution of the OKT4 antigen on lymphocytes: studies in three black families. Thymus. 7:357-366.

33. Lindsten, T., C. H. June, J. A. Ledbetter, G. Stella, and C. B. Thompson. 1989. Regulation of lymphokine messenger RNA stability by a surface-mediated T cell activation pathway. Science (Wash. DC). 244:339-343.

34. Shaw, J., K. Meerovitch, R. C. Bleackley, and V. Paetkau. 1988. Mechanisms regulating the level of IL-2 mRNA in T lymphocytes. J. Immunol. 140:2243-2248.

35. Koide, S., K. Inaba, and R. M. Steinman. 1987. Interleukin 1 enhances T-dependent immune responses by amplifying the function of dendritic cells. $J$. Exp. Med. 165:515-530.

36. Depper, J. M., W. J. Leonard, C. Drogula, M. Krönke, T. A. Waldmann, and W. C. Greene. 1985. Interleukin 2 (IL-2) auguments transcription of the IL-2 receptor gene. Proc. Natl. Acad. Sci. USA. 82:4230-4234.

37. Noma, T., T. Mizuta, A. Rosen, T. Hirano, T. Kishimoto, and T. Honjo. 1987. Enhancement of the interleukin 2 receptor expression on T cells by multiple B-lymphocytic lymphokines. Immunol. Lett. 15:249-253.

38. Lowenthal, J. W., D. W. Ballard, H. Bogerd, E. Böhnlein, and W. C. Greene. 1989. Tumor necrosis factor- $\alpha$ activation of the IL-2 receptor- $\alpha$ gene involves the induction of $\kappa \mathrm{B}$-specific DNA binding protein. J. Immunol. 142:3121-3128.

39. Kuno, M., and P. Gardner. 1987. Ion channels activated by inositol 1,4,5,triphosphate in plasma membrane of human T-lymphocytes. Nature (Lond.). 326:301-304.

40. Gelfand, E. W., G. B. Mills, R. K. Cheung, J. W. W. Lee, and S. Grinstein. 1987. Transmembrane ion fluxes during activation of human $T$ lymphocytes: role of $\mathrm{Ca}^{2+}, \mathrm{Na}^{+} / \mathrm{H}^{+}$exchange and phospholipid turnover. Immunol. Rev. 95:59-87.

41. Goldsmith, M. A., and A. Weiss. 1988. Early signal transduction by antigen receptor without commitment to $\mathrm{T}$ cell activation. Science (Wash. DC). 240:1029-1031.

42. Ledbetter, J. A, C. H. June, P. S. Rabinovitch, A. Grossmann, T. T. Tsu, and J. B. Imboden. 1988. Signal transduction through CD4 receptors: stimulatory vs inhibitory activity is regurated by $\mathrm{CD} 4$ proximity to the $\mathrm{CD} 3 / \mathrm{T}$ cell receptor. Eur. J. Immunol. 18:525-532.

43. Rosoff, P. M., S. J. Burakoff, and J. L. Greenstein. 1987. The role of the L3T4 molecule in mitogen and antigen-activated signal transduction. Cell. 49:845-853.

44. Tamura, T., J. Mizuguchi, and $H$. Nariuchi. 1990. Regulatory role of CD4/L3T4 molecules in IL-2 production by affecting intracellular $\mathrm{Ca}^{2+}$ concentration of $T$ cell clone stimulated with soluble anti-CD3. J. Immunol. 145:78-84.

45. Weiss, A., G. Koretzky, R. C. Schatzman, and T. Kadlecek. 1991. Functional activation of the T-cell antigen receptor induces tyrosine phosphorylation of phospholipase C- $\gamma 1$. Proc. Natl. Acad. Sci. USA. 88:5484-5488.

46. Weissman, A. M., P. Ross, E. T. Luong, P. Garcia-Morales, M. L. Jelachich, W. E. Biddison, R. D. Klausner, and L. E. Samelson. 1988. Tyrosine phosphorylation of the human $\mathrm{T}$ cell antigen receptor $\zeta$-chain: activation via CD3 but not CD2. J. Immunol. 141:3532-3536.

47. Nishibe, S., M. I. Wahl, S. M. T. Hernandez-Sotomayor, N. K. Tonks,
S. G. Rhee, and G. Carpenter. 1990. Increase of the catalytic activity of phospholipase C- $\gamma 1$ by tyrosine phosphorylation. Science. (Wash. DC). 250:1253-1256.

48. Mustelin, T., K. M. Coggeshall, N. Isakov, and A. Altman. 1990. T cell antigen receptor-mediated activation of phospholipase $\mathrm{C}$ requires tyrosine phosphorylation. Science. (Wash. DC). 247:1584-1587.

49. June, C. H., M. C. Fletcher, J. A. Ledbetter, G. L. Schieven, J. N. Siegel, A. F. Phillips, and L. E. Samelson. 1990. Inhibition of tyrosine phosphorylation prevents T-cell receptor-mediated signal transduction. Proc. Natl. Acad. Sci. USA. 87:7722-7726.

50. Klausner, R. D., and L. E. Samelson. 1991. T cell antigen receptor activation pathways: the tyrosine kinase connection. Cell. 64:875-878.

51. Sleckmann, B. P., A. Peterson, J. A. Foran, J. C. Gorga, C. J. Kara, J. L. Strominger, S. J. Burakoff, and J. L. Greenstein. 1988. Functional analysis of a cytoplasmic domain-depleted mutant of the CD4 molecule. J. Immunol. 141:49 54.

52. Glaichenhaus, N., N. Shastri, D. R. Littman, and J. M. Turner. 1991. Requirement for association of $\mathrm{p} 56^{\text {lck }}$ with CD4 in antigen-specific signal transduction in T cells. Cell. 64:511-520.

53. Mazerolles, F., A. Durandy, D. Piatier-Tonneau, D. Charron, L. Montagnier, C. Auffray, and A. Fisher. 1988. Immunosuppressive properties of synthetic peptides derived from CD4 and HLA-DR antigens. Cell. 55:497-504.

54. Lamarre, D., A. Ashkenazi, S. Fleury, D. H. Smith, R. P. Sekaly, and D. J. Capon. 1989. The MHC-binding and gp 120-binding functions of CD4 are separable. Science (Wash. DC). 245:743-746.

55. Marth, J. D., J. A. Cooper, C. S. King, S. F. Ziegler, D. A. Tinker, R. W. Overell, E. G. Krebs, and R. M. Perlmutter. 1988. Neoplastic transformation induced by an activated lymphocyte-specific protein tyrosine kinase (pp56 ${ }^{\mathrm{kk}}$ ). Mol. Cell. Biol. 8:540-550.

56. MacAuley, A., and J. A. Cooper. 1988. The carboxy-terminal sequence of p56lck can regulate p60c-src. Mol. Cell. Biol. 8:3560-3564.

57. Koretzky, G. A., J. Picus, M. L. Thomas, and A. Weiss. 1990. Tyrosine phosphatase CD45 is essential for coupling T-cell antigen receptor to the phosphatidyl inositol pathway. Nature (Lond.). 346:66-68.

58. Schraven, B., H. Kirchgessner, B. Gaber, Y. Samstag, and S. Meuer. 1991. A functional complex is formed in human $\mathrm{T}$ lymphocytes between the protein tyrosine phosphatase CD45, the protein tyrosine kinase $\mathrm{p} 56^{\text {lck }}$ and pp32, a possible common substrate. Eur. J. Immunol. 21:2469-2477.

59. Juszczak, R. J., H. Turchin, A. Truneh, J. Culp, and S. Kassis. 1991. Effect of human immunodeficiency virus gp1 20 glycoprotein on the association of the protein tyrosine kinase p56lck with CD4 in human T lymphocytes. J. Biol. Chem. 266:11176-11183.

60. Hatakeyama, M. M., M. Tsudo, S. Minamoto, T. Kono, T. Doi, T. Miyama, M. Miyasaka, and T. Taniguchi. 1989. Interleukin-2 receptor beta chain gene: generation of three receptor forms by cloned human alpha and beta cDNA's. Science (Wash. DC). 244:551-556.

61. Horak, I. D., M. Popovic, E. M. Horak, P. J. Lucas, R. E. Gress, C. H. June, and J. B. Bolen. 1990. No T-cell tyrosine protein kinase signalling or calcium mobilization after CD4 association with HIV-1 or HIV-1 gp120. Nature (Lond.). 348:557-560.

62. Tsuchida, T., and T. Sakane. 1988. Intracellular activation signal requirements for the induction of IL-2 responsiveness in resting $T$ cell subsets in humans. J. Immunol. 140:3446-3449.

63. Erard, F., M. Nabholz, A. Dupuy-D'Angeac, and H. R. MacDonald. 1985. Differential requirements for the induction of interleukin 2 responsiveness in $\mathrm{L}^{2} 4^{+}$and Lyt-2 ${ }^{+} \mathrm{T}$ cell subsets. J. Exp. Med. 162:1738-1743.

64. Reed, J. C., A. H. Abidi, J. D. Alpers, R. G. Hoover, R. J. Robb, and P. C. Nowell. 1986. Effect of cyclosporin A and dexamethasone on interleukin 2 receptor gene expression. J. Immunol. 137:150-155.

65. Tocci, M. J., D. A. Matkovich, K. A. Collier, P. Kwok, F. Dumont, S. Lin, S. Degudicibus, J. J. Siekierka, J. Chin, and N. I. Hutchinson. 1989. The immunosuppressant FK506 selectively inhibits expression of early $\mathrm{T}$ cell activation genes. J. Immunol. 143:718-726.

66. Boumpas, D. T., E. D. Anastassiou, S. A. Older, G. C. Tsokos, D. L. Nelson, and J. E. Balow. 1991. Dexamethasone inhibits human interleukin 2 but not interleukin 2 receptor gene expression in vitro at the level of nuclear transcription. J. Clin. Invest. 87:1739-1747.

67. Dumont, F. J., M. J. Staruch, S. L. Koprak, M. R. Melino, and N. H. Sigal. 1990. Distinct mechanisms of suppression of murine $T$ cell activation by the related macrolides FK-506 and rapamycin. J. Immunol. 144:251-258.

68. Mattila, P. S., K. S. Ullman, S. Fiering, E. A. Emmel, M. McCutcheon, G. R. Crabtree, and L. A. Herzenberg. 1990. The action of cyclosporine A and FK506 suggest a novel step in the activation of T lymphocytes. EMBO (Eur. Mol. Biol. Organ.) J. 9:4425-4433.

69. Cross, S. L., N. F. Halden, M. J. Lenardo, and W. J. Leonard. 1989. Functionally distinct NF-kB binding sites in the immunoglobulin $\kappa$ and IL-2 receptor $\alpha$ chain genes. Science (Wash. DC). 244:466-469.

70. Meichle, A., S. Schütze, G. Hensel, D. Brunsing and M. Krönke. 1990 Protein kinase $C$-independent activation of nuclear factor $\kappa \mathrm{B}$ by tumor necrosis factor. J. Biol. Chem. 265:8339-8343.

71. Rosoff, P. M. N. Savage, and C. A. Dinarello. 1988. Interleukin-1 stimulates diacylglycerol production in T lymphocytes by a novel mechanism. Cell. 54:73-81. 